\title{
Event review: Center for American Archeology Flintknapping Workshop with Tim Dillard, Kampsville, Illinois, U.S.A.
}

\author{
Jeanne Day Binning \\ Central California Cultural Resources Branch, Central Region Environmental Division, 855 M Street, Suite 200, \\ Fresno, CA 93721, U.S.A. Email: jeanne.binning@dot.ca.gov
}

The Center for American Archeology (CAA), located in Kampsville, Illinois, USA has been a leader in archaeological research, education, and cultural stewardship for over 60 years. The CAA continues to be an important and cutting edge institution in the development of innovative research, educational programing, and the promotion of heritage education in the United States. For much of its history, the CAA annually has taught flintknapping as a skill that facilitates the understanding of the archaeological record and a practice that generates interest in the past. Currently, the CAA offers the Flintknapping Workshop with Tim Dillard. This workshop is held each year during the last week of May and offers both experienced and novice knappers the opportunity to learn traditional flintknapping techniques.

"Flintknapping" is a popular recreational activity in the United States; however, most flintknapping activities, workshops, and events are more accurately characterized as folkknapping. This is a tradition in which stone tools are made with non-traditional, non-authentic tools, techniques, and materials.

For the archaeologist who wishes to apply learned flintknapping skills to the understanding of the archaeological record, the five-day Tim Dillard Workshop hosted by the CAA is the best traditional (non-folk-knapping) flintknapping class known to this writer. Class activities included selecting appropriate chert from the local environment; spalling and preforming raw material with hammerstones; heat treating chert; using an antler billet to perform percussion biface reduction; and pressure flaking of both flakes and bifaces to produce projectile points, thrusting spear points, and knives. Dillard is an unmatched traditional flintknapper and an exceptional teacher. During the five-day experience, participants received one-on-one instruction. Every stage of the reduction process was explored from selecting nodules to finishing a well-crafted bifacial tool. Dillard makes time to work individually with all students attending the workshop and has the ability to teach towards any skill level. All participants received the (ample) attention needed to learn traditional flintknapping techniques. This workshop did not disappoint and is highly recommended for those who wish to acquire flintknapping skills to aid in experimental archaeology and lithic analysis.

Published by the School of History, Classics and Archaeology, University of Edinburgh ISSN: 2055-0472. URL: http://journals.ed.ac.uk/lithicstudies/

This work is licensed under a Creative Commons Attribution 2.5 UK: Scotland License. 
More information about this workshop can be found online at the Center for American Archeology's website: http://www.caa-archeology.org/programs/flintknapping/ Inquiries about the workshop can be received at caa@caa-archeology.org or 1-618-653-4316.

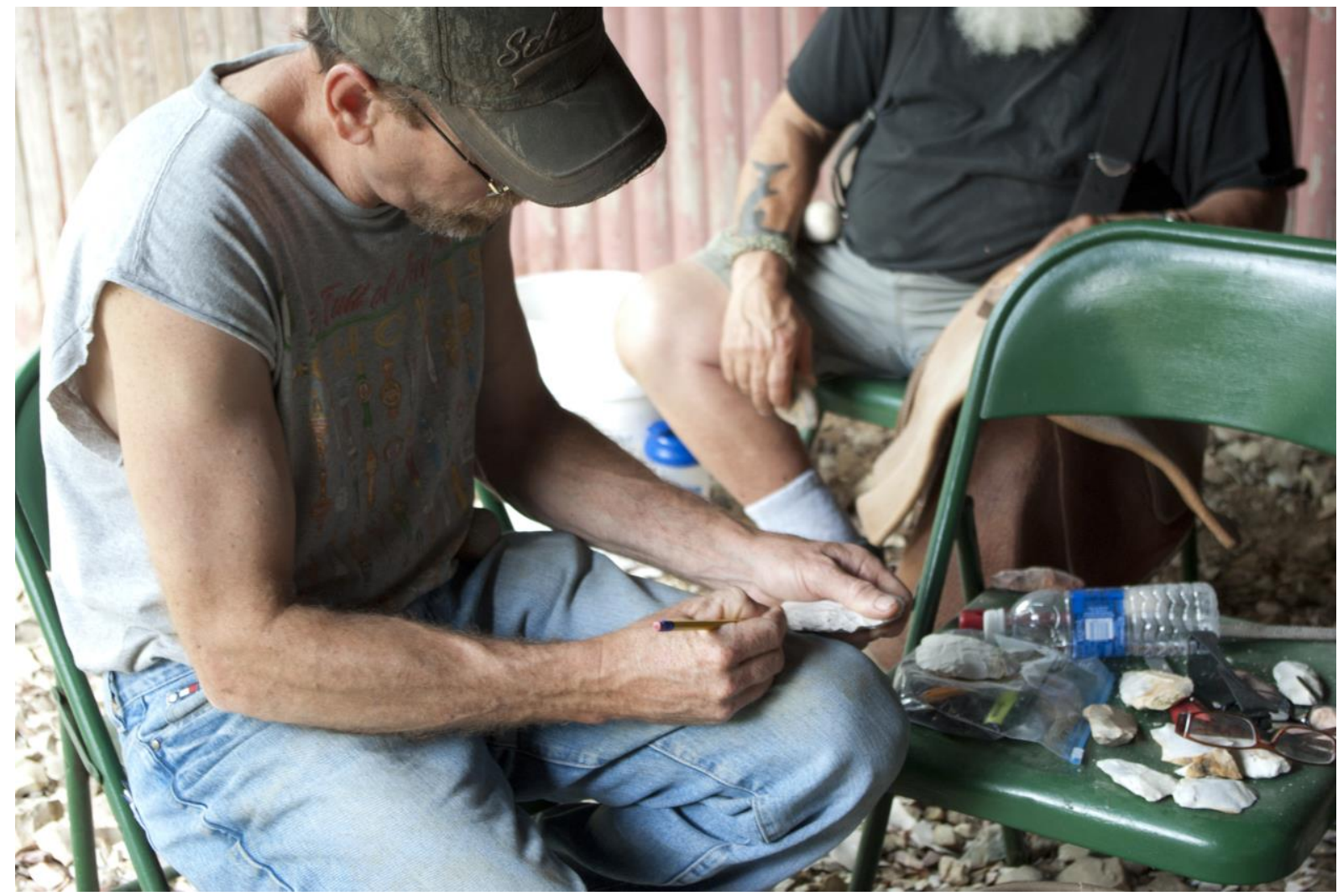

Figure 1. Expert traditional knapper, Tim Dillard, instructs students in where and how to remove flakes in the production of a biface. (Photo by Center for American Archeology.)
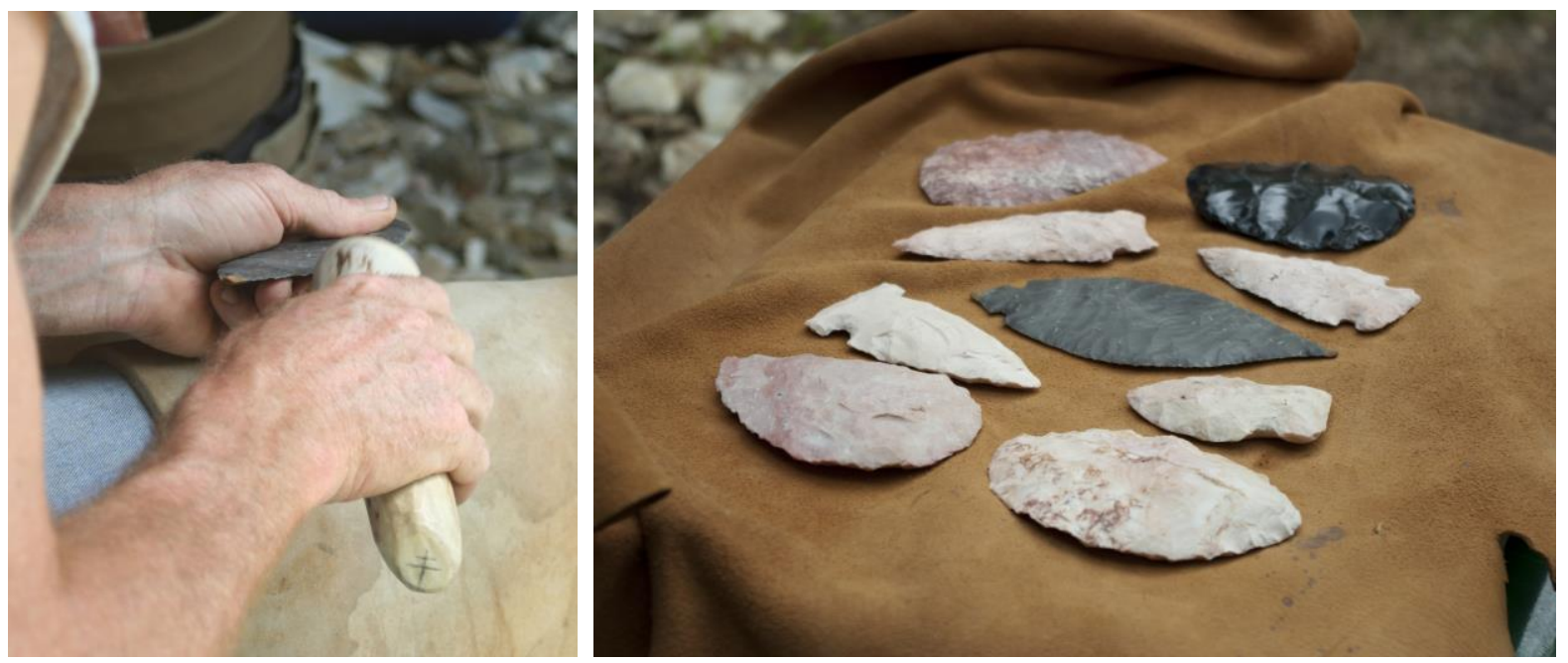

Figure 2 (left). Tim Dillard thinning a Turkey Tail biface. These artifacts were found in sacred contexts and exceptionally difficult to produce. Tim's skill level in billet percussion is unmatched. (Photo by Jeanne Binning.) Figure 3 (right). Biface performs, atlatl dart points, and knifes made by students and Tim Dillard with both local and non-local materials. (Photo by Center for American Archeology.) 